\title{
MAI TE KORE KI TE AO MĀRAMA: A JOURNEY FROM THE DARKNESS TOWARD THE LIGHT
}

\author{
Na Vicki Rangitautehanga Murray
}

\section{INTRODUCTION}

He kai kei aku ringa, engari anō te kai mo te tinana, he kai tēnei o te rangatira; ara, he kōrero, he kōrero, he kōrero. Ahakoa he iti, he paku whakarāpopoto i tētahi tirohanga atu ki ētahi o ngā mohotanga, ngā hua oranga ake i aku wāhi mahi i roto i te hapori. He rahi ake ngā rauemi o ngāi tāua kia hangai tonu atu ki te whakaaro a o tātou tipuna, erangi ka whai atu aku whakaaroake i ngā momo rerenga kupu e rua; ko te tauparapara me te whakataukī. Kua tukuna atu ahau he kīanga hou mo te whakaakoranga o te tangata ki a ia anō' kia;'he wheku mataara' ${ }^{2} \mathrm{i}$ te tuhinga e whai ake nei.

As we are concerned with innovation in professional practice in the age of disruption, I want to preface my remarks by signaling the relationship between the title of this submission and the theme of transformation. In my situation, innovation arises in the developmental journey of my professional practice. As a new practitioner, darkness is a place of unknowing: I find myself gradually moving toward the light with the gaining and application of knowledge over time. After years of practice and reflection on practice and the refinement of practice, the journey to enlightenment is continuous.

Colonisation continues to be the primary disruption for Māori. Subjected to almost two hundred years of marginalisation, discrimination and white privilege, it is no wonder Māori moulder at the bottom of the heap. Born Māori, this inheritance is not my legacy of choice. I opt instead to explore the possible boundaries of change through my professional practices in social work, supervision and in teaching.

This article profiles verse in the shape of an ancient chant (he tauparapara) as a prism for an autoethnographic discovery of professional practice through professional epochs of my life. It also uses footnotes as a way of bringing my bilingual scope into this narrative, at the same time considering the needs of non-bilingual and international readers. Metaphors (whakataukī) feature as a lens through which to accentuate learnings gained from my professional journey from darkness or uncertainty toward elucidation. Metaphorical sayings are also expressions that 'restory' elements of my practice in parallel with ancestral genres in the Māori world.

\section{ME HOKIWHAKAMURI KIA ANGA WHAKAMUA THE FUTURE IS INFORMED BYTHE PAST}

Looking back now over an eight-year period, I can discern a clear but gradual shift away from mainstream statutory social work roles (although it had not been a conscious decision) to positions in tribal governance, and then into the Māori provider education, social and health sectors. On a day no different than any other, as a tutor on the social work programme, I overheard several students on the Māori language course cheefully chatting away to each other

I That is, autoethnography.

2 He wheku mataara offers a perspective perhaps best described as an omniscient alertness (a renaming of autoethnography). 
in Māori.Turning to a colleague, I asked if she knew what they were saying. She said no, but that she really wished she could. Right then and there I decided I would like to understand them, too, and enrolled in the next available course.

"E! Kia whakatāne ake au i ahau!"

My ancestor Wairaka's famous exclamation, translated as "Let me now be as a man," is a call to take responsibility and also to take action. The following six years would find me totally immersed in wānanga ${ }^{3}$ mātauranga Māori. ${ }^{4}$ Comparable to Tāne's ascension to the heavens to receive the baskets of knowledge, ${ }^{5}$ I would need to overcome some obstacles. The first was humbling myself by stepping into the unknown, ${ }^{6}$ a place where I knew next to nothing about the Māori language or the multiple relational layers marking the pathway to Māori learning. In order to receive new knowledge I had to undergo cleansing, set aside my 'educatedness' and fully engage in the process of decolonisation. I had to disrupt and reset my autopilot by embracing the gifts held in the sacred basket, Aronui, which supports the embodiment of love and peace as well as literature, philosophy and humanities.

\section{Bold acts and words proclaimed Arise! Valiant maiden}

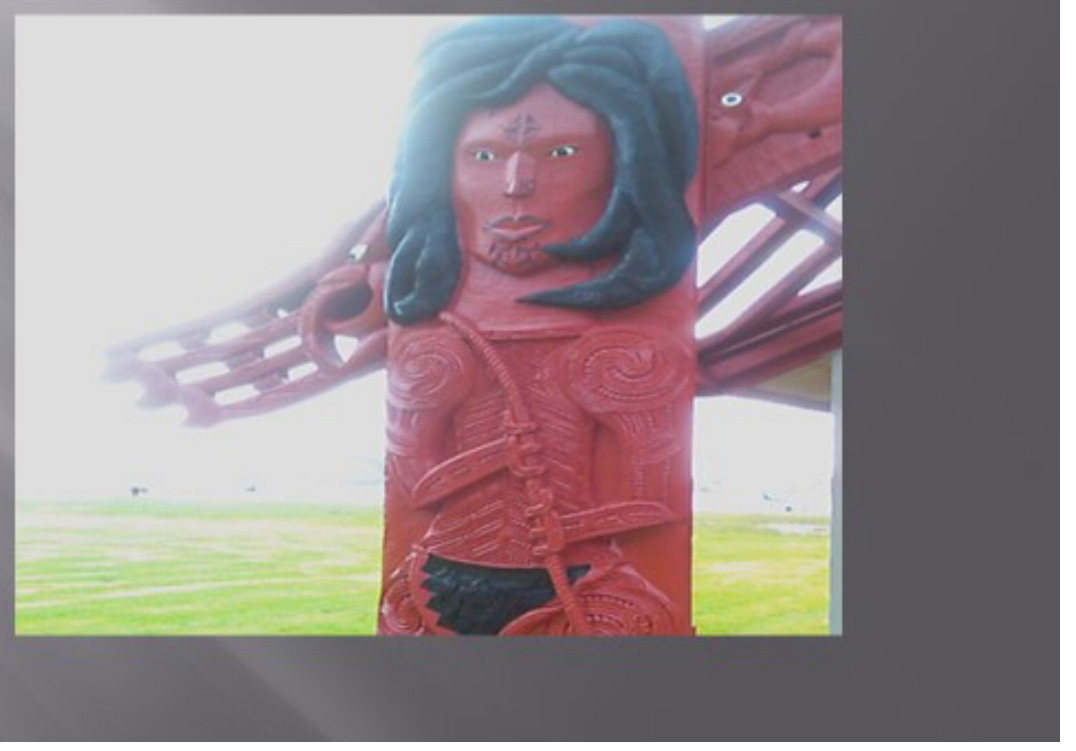

\section{KIA ARO KITE HĀ O TETANGATA PAY HEED TO THE PERSON}

The wisdom and patience of the wānanga tutors in the presence of my self-doubt and uncertainty got me through each tenuous stage of learning. Gradually I began to think, view and articulate attitudes from a Māori perspective more distinctly. Work and study went hand in hand; as I learnt more, I applied more of the learnings as samplers into

3 An environment or learning institution which caters for Māori learners and their needs.

4 Māori knowledge - the body of knowledge originating from Māori ancestors, including Māori creativity and cultural practices.

5 Ko Te Kete Tuāuri, ko Te Kete Tuātea, ko Te Kete Aronui, ko Te Kete Aroiti (Karetu, 2008).

6 Te kore - the first state of being, of chaos, almost nothingness and the stirring of potential. 
my own teaching practice and my confidence grew. It was during a critical reflection interchange that I realised a new version of me had morphed - the changes were noticeable in my practice. Implementing te reo me ōna tikanga ${ }^{7}$ into my life was analogous to passing through huaki pōuri, ${ }^{8}$ a portal to illumination, an organic way of seeing, being and expressing myself as a Māori working with and for Māori, inside organisations delivering services to improve outcomes for Māori. Deeply grateful for my learnings, I felt it was time to share the potency of karakia, mōteatea, waiata, pūrākau, whakapapa (recitation, chanting, song, storytelling, genealogy) and other cultural instruments with my communities of practice.

\section{A Chant to Ancestral Landscapes}

My journey begins at Pōhaturoa

There spirits of ancestors repose

Deliberation at Wharaurangi

Ascend to Pāpaka and Puketapu

O'er yonder to sky palisade

To thee progeny of Toi eternal keepers of the land

Wairere gushing forth liquid sustenance

Navigators' signposts

Turn inward there Hine's pouted lips

Bold acts and words proclaimed

Arise! Valiant maiden

O'er, under, never more seen

Guardians, custodians

Sentinels, denizens

Lift mine eyes yon sandy estuary

Neither burial track n'er kith nor kin

Soar out beyond inshore currents

To volcanic isle quietly smouldering

Cast landward to thee

Oh, mountain who walked

Pütauaki - the caverns of Rēhua

To Mataatua carved house where altared mānuka stands

For those of Awa,

Of Pükeko

It is there, it is there!

$7 \quad$ The inherent connection between language and culture.

8 The research methodology relating to Te Tohu o Te Reo Māori with Te Pū Wānanga o Anamata. This approach is also found in the Maui stories recorded by Wiremu Maihi Te Rangikāheke (Thornton, 1999). 
"A Chant to Ancestral Landscapes"' was composed while studying for the Bachelor of Te Reo Māori. The chant is a collection of vignettes of Ngāti Awa ancestors told in poetry and traditional sayings. Each parable is grounded in wisdoms of foremothers and forefathers and together serve as character and performance blueprints for ensuing generations. A selection of photoscapes (photographed landscape portraits) feature as an elaboration of the artistic and poetic imagery presented here in order to convey my distinctive ancestral essence to my Scope audience.

\section{$\bar{A}, K A$ OHO AKETŌKU MAURI MY LIFE FORCE IS FULLY AROUSED}

My research into and the composition of "A Chant to Ancestral Landscapes" was a magical experience, as during that juncture of life my mind, heart and spirit were awakened to the immeasurable treasures of the Māori world. Although at the outset I had known that the chant was more than an excursion from land, river and ocean bases, over time, in the recitation and particularly in the incantation of these verses, a deep sense of having found my place in the world unfolded.

Influenced by an aroused life force, I navigated seamlessly into a Masters degree to gather evidence for Hoki ki tou maunga kia purea ai e koe ki ngā hau o Tāwhirimātea ${ }^{10}$ - a tangata whenua (people of the land) model of supervision. This model of supervision is an extension of "A Chant to Ancestral Landscapes." In the beginning, I would go to specific locations with a supervisee, opening our kōrero with a thematic dialogue on the ancestor associated with that place as a preamble to matters they wanted to reflect on.

I was then asked to take a collective of educators from an organisation for cultural supervision on these visits. These folk were all specialists in their field, employed to intergrate children excluded from schools back into the education system. All the educators and the children they worked with identified as Māori. In order to bring about long-term change for each child, appropriate supports were provided for the whānau, too. While the kaimahi were achieving positive results by implementing cultural strategies and processes, they were receiving scant recognition, support or resources to fulfil the demands of their role. They felt undervalued and isolated. To help find resolutions to the situation they requested cultural supervision, which I was to provide.

Over the next year the cluster came together bimonthly for gatherings, and by consensus they renamed the process "tangata whenua supervision." The site for each session was chosen by a different member of the group who became the lead facilitator. The team supported the facilitator in their preparations, as several of the visits were 'noho wānanga,' beyond the official sites of learning. As tangata whenua, the lead facilitator played host to the group and delivered (or facilitated the delivery of) the protocols relevant to their ancestry and ancestral domain. As participants were unable to access further funding, the sessions ended. However, as a consequence, the team had developed a strong cohesion over time, which led them to meet regularly, helping to counter the disadvantages of working in isolation and providing them with a forum which valued cultural competencies.

After receiving particularly favourable responses from all involved in the group sessions, I decided to submit "Hoki ki tou maunga - A tangata whenua model of supervision" as my research project.

In the pursuit of knowledge, one is able to see the world from another vantage point - such as the vista offered from Pāpaka and Puketapu, looking out over the Moana-a Toi, Motu Tohorā and Te Puia o Whakaari glimmering on the distant horizon. In the maxim "Kimihia te kahurangi" (see below), kahurangi refers to a Māori epistemological and ontological position of seeking knowledge. Five years on, the research project completed and the hoki ki tou maunga - tangata whenua model of supervision firmly established, I am positioned to ascend to the next summit.

$9 \quad$ He Tauparapara Toka Tipua - this is an abridged English-language version provided for Scope. See Murray, 2017, pp. 39-42 for the original text.

I0 "Return to your mountain to be cleansed by the winds of Tawhirimātea" (the Māori god of winds and storms). 


\section{Ascend to Pāpaka and Puketapu Out posts o'er distant horizons}

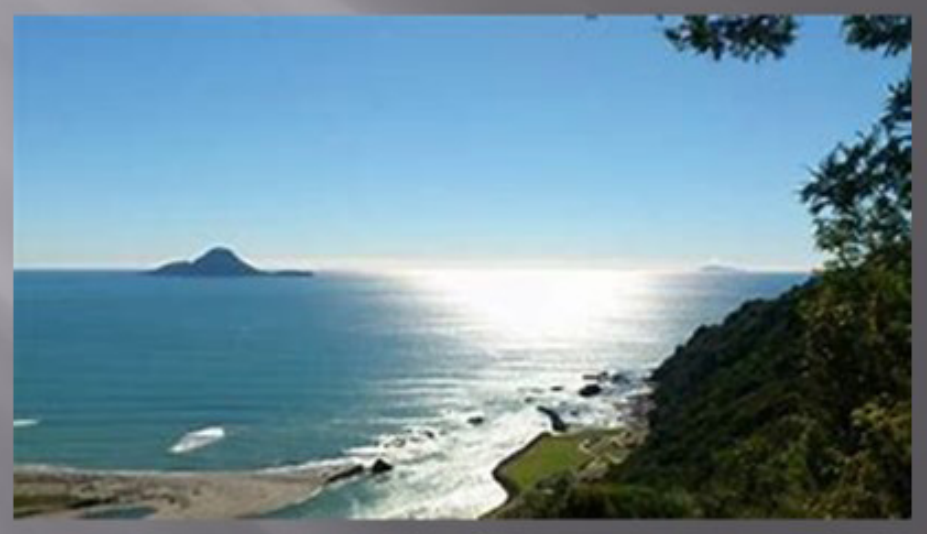

\section{KIMIHIA TE KAHURANGI \\ SEEK THAT WHICH IS OFTHE HIGHEST VALUE}

\section{KIA MAU KITO UKAIPŌ HOLD FASTTO THAT WHICH NOURISHESYOU AND BRINGSYOU SUSTENANCE}

A constant in my relational learning continuum, "A Chant to Ancestral Landscapes" has literally become my rock standing firm in the ocean (he toka tu moana), and as such is the perfect conduit to reflect on my professional practice and to situate the learning gained from those experiences in a socio-genealogical geographical continuum. It has been a quest, an exploration of the self in practice (Arnold, $20 \mathrm{II}$ ). For this reason, "A Chant to Ancestral Landscapes" has in effect become a declaration of me as a Māori woman, as a decendent of Ngāti Awa, but also as a professional in practice who is has Ngāti Awa ancestry. Most notably, though, it has not only provided a kaupapa Māori framework, but a specifically Ngāti Awa professional practice framework.

Autoethnography descriptors include phrases such as "the self as data," "analytic observation through the prism of self" (Arnold, 20 I I) and, as Chang (2008) puts it, the self as a window into cultural experience. However, in order to align with "A Chant to Ancestral Landscapes," my framework of professional practice, and to provide a culturally fitting alternative, I propose the phrase "he wheku mataara."Wheku are the slanted designs around the eyes seen on the koruru, the carved figure standing above the apex of the carved house on the marae. From this vantage point, the koruru has a I80-degree view beyond the marae, his senses ever on the alert.

Māori philosophy is central to my practice. Thanks to the efforts of cultural protagonist Linda Tuhiwai Smith (1996) and the numerous advocates of Kaupapa Māori Theory, Māori values, principles, processes and traditions are now 
established and accepted as normal. To suggest he wheku mataara as a more appropriate expression of the self seen as as a window onto cultural experience is also an assertion of Māori cultural positioning in a field which, on the whole, still privileges the dominant other. However, just as ancestors Toi, Toroa and Awa-nui-ā-rangi explored land and sea territories in a process of discovery, " I have adopted a pluralist, broadly inclusive approach in order to cultivate my imagination, to allow me to soar out beyond my current horizons.

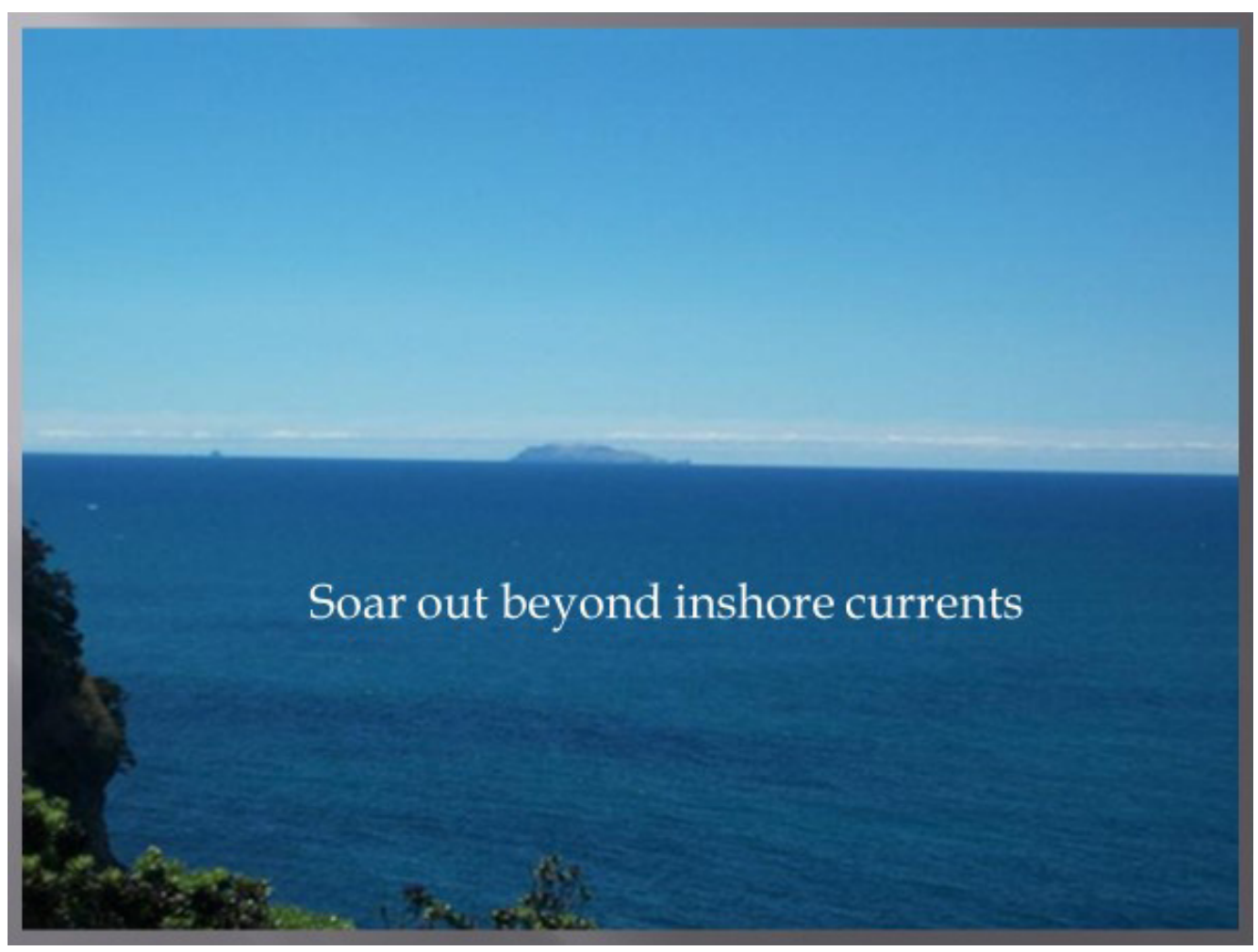

In The Healing Power of Stories (1996), Taylor insists everyone has a story to tell. As an expression of the truths of my experiences, he wheku mataara means that I am my story and my story has meaning. The value of being and becoming through learning, as much as knowing and doing, is at the heart of my personal and professional journey. The two are intimately entwined. My experiences as a learner became the foundational standard for my teaching practice. For these reasons, I make sure that I pay heed to the learner or supervisee, seeking to nurture them so that their mauri remains intact. He wheku mataara assumes the duplexity of the familiarity of phenomena as a method of inquiry. In the end, he wheku mataara allows me to tell my story within the collective narratives of "A Chant to Ancestral Landscapes" as an emic or intimate subjective insider. Although contrary to traditional (Western) research practices, where the researcher seeks to remain at a distance and be objective, the notion of the self as a window onto cultural experiences mirrors the connection that indigenous researchers have with their people and culture.

He wheku mataara has fashioned cornerstone moments that have been influential in my development in professional practice. When considering Arnold's (20I I) concept of "the self as data," my first insight was the strong desire to work with my own people in ways that would lead them through the state of mauri mate to mauri ora. ${ }^{12}$ I then had to aquire the skills to work most effectively to achieve these outcomes. Furthermore, resources were required to support these practice intentions. In hindsight, it should have been a straightforward venture, as ancestral templates and wise mentors (tuākana) have always been here to guide us, to guide me. I had to walk the path into the Māori

II During the early migration voyages from Hawaiki to Aotearoa.

12 "From a languishing to a flourishing disposition." 
world to see them. That pathway for me was learning the language of my ancestors, te reo Māori. In my application of he wheku mataara, I realised that even in the early days, although I was blinded or blinkered by the insidious colonial condition both culturally and academically, critical reflection had always been integral to my practice. This insight is substantiated in the multiple transformations gained from each learning trajectory associated with my professional practice.

\section{CONCLUSION}

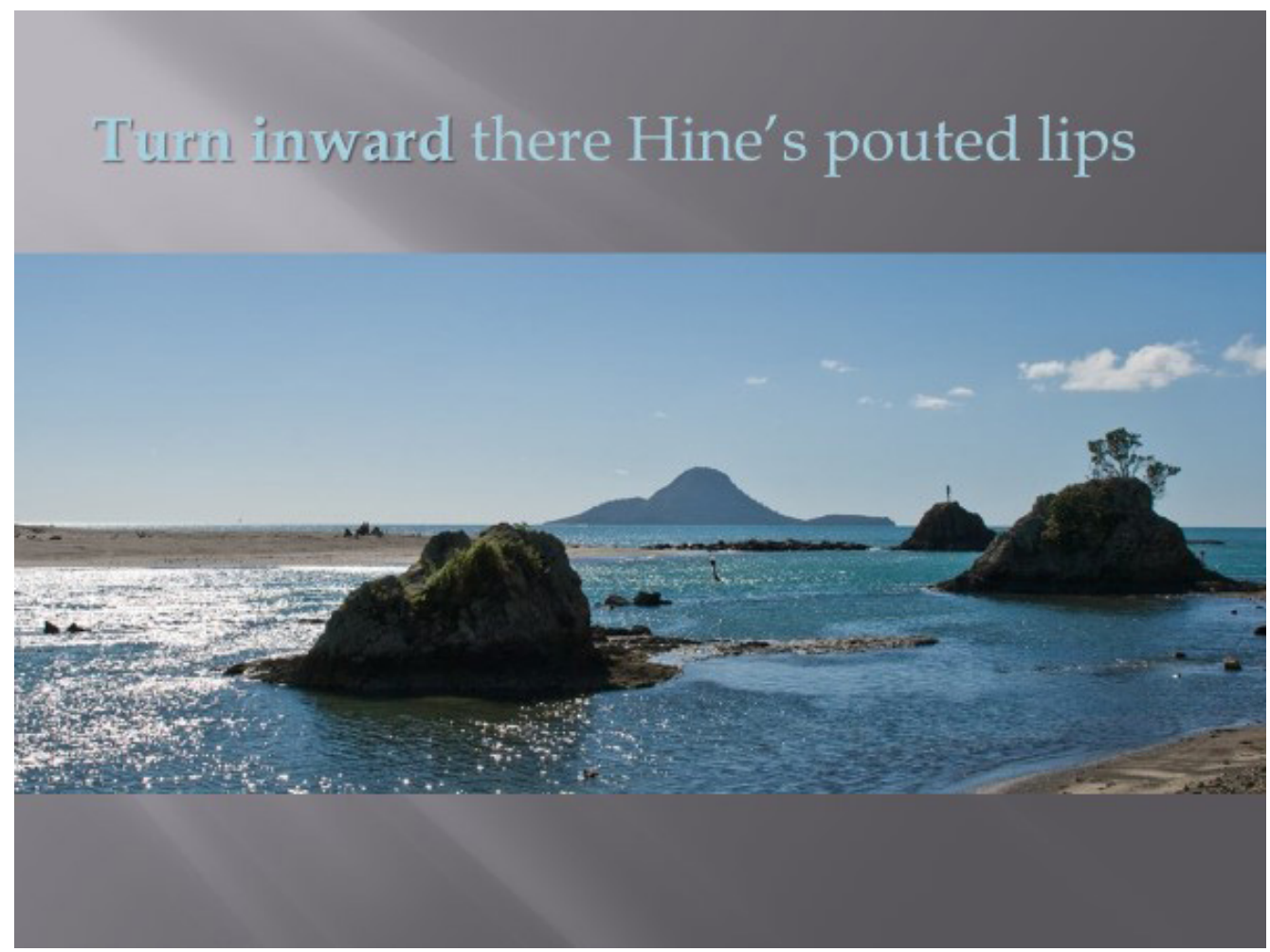

Te kete Aronui - one of the three baskets of knowledge - refers to the methodology of consequential processes of inquiry that I have adopted in the pursuit of knowledge on my journey from the darkness toward the light. Residing within it is he wheku mataara, an analytic observation through the prism of self. Thus I am able to expand on what is working at any given time and to identify components of practice that I can improve upon. Angel Arrien's wisdom of the teacher reminds me to be flexible and open to possibilities not yet considered. In this context, he wheku mataara is a prompt that encourages an omniscient approach to any learning, practice or research opportunities that may come my way. Exercising vigilance even in times of disruption, a light can always be found to create a brighter future for my communities of practice.

Reaching the light is not a landing place. Like the water surging through Ōhinemataroa (Hine's lips), the mouth of the Whakatāne River, out to the ocean of Toi, this elusive goal is in perpetual motion. As the river ebbs and flows, the rocks (my professional practices) are cleansed and restored by the sharing of my cultural self in professional practice with you.

Otirā, tēna koe, tēna tātou katoa. 
Although Vicki Rangitautehanga Murray writes here about her Ngāti Pukeko and Ngāti Awa ancestry, she also has links to Te Whānau-ā-Apanui and Ngāpuhi. She is a tutor, providing mentoring, cultural training and tangata whenua supervision to clinicians working with therapeutic communities of practice in rehabilitation faciltities. Vicki is also a director, board member, trustee and committee member for her iwi, ahu whenua trusts and marae. Her doctoral research will consider Māori instruments of practice as guides to inspire Māori leadership to thrive in times of dynamic change.

Contact details: murrayvicki0 I@gmail.com

Adams, T. E., Holman Jones, S., \& Ellis, C. (2015). Autoethnography. Oxford, UK: Oxford University Press.

Adds, P., Hall, M., Higgins, R., \& Higgins, T. (20I I). Ask the posts of our house: Using cultural spaces to encourage quality learning in higher education. Teaching in Higher Education, I 6(5), 54I-55I.

Arnold, J. (20II). The self as data: A qualitative methodology. Journal of Educational and Developmental Psychology, I I ( I), 65-73.

Arrien, A. (1993). The Four-fold way: Walking the paths of the warrior, teacher, healer, and visionary. San Francisco, CA: HarperOne.

Barlow, C. (1994). Tikanga whakaaro: Key concepts in Māori culture. Auckland, NZ: Oxford University Press.

Chang, H. (2008). Autoethnography as method. Walnut Creek, CA: Left Coast Press.

Dewey, J. (1933). How we think: A restatement of the relation of reflective thinking to the educative process. Boston, MA: Houghton Mifflin.

Durie, M. (200I). Mauri ora:The dynamics of Maori health. Auckland, NZ: Oxford University Press.

Ellis, C. (2004). The Ethnographic I:A methodological novel about autoethnography. Walnut Creek, CA: Altamira Press.

Fook, J. (2007). Reflective practice and critical reflection. In L. Lishman (Ed.), Handbook for practice learning in social work and social care: Knowledge and theory (pp. 363-375). London, UK: Jessica Kingsley.

Jones, S., \& Metge, J. (1995). He taonga tuku lho nō ngā tūpuna: Māori proverbial sayings - A literary treasure. Journal of New Zealand Studies, 5(2), 3-7. https://doi.org/l0.26686/jnzs.v5i2.47।

Karetu, T. (2008). Te kete tuawhā, te kete aronui - The fourth basket. Te Kaharoa Journal, I(I), 86-99. https://doi.org/I0.24I35/ tekaharoa.vlil.135

Lee, J. (2009). Decolonising Māori narratives: Pūrākau as a method. MAl Review, 2, Art. 3.

Marsden, M. (2003). The woven universe: Selected writings of Rev. Māori Marsden. Masterton, NZ: Estate of Rev. Māori Marsden.

Mead, H. M., \& Grove, N. (2000). Nga pepeha a nga tipuna:The sayings of the ancestors. Wellington, NZ:Victoria University Press.

Mead, S. M. (1997). Landmarks, bridges and visions: Aspects of Māori culture: Essays. Wellington, NZ:Victoria University Press.

Mezirow, J. (1975). Transformative learning:Theory to practice. New Directions for Adult and Continuing Education, 74, 5-12.

Mezirow, J. (1990). How critical reflection triggers transformative learning. In J. Mezirow (Ed.), Fostering critical reflection in adulthood: A guide to transformative and emancipatory learning (pp. I-20). San Francisco, CA: Jossey-Bass.

Murray, V. R. (2017). Hoki ki tōu maunga kia purea ai koe ki ngā hau o Tāwhirimātea - A tangata whenua model of supervision [Unpublished thesis for a Masters in Social \& Welfare]. University of Otago, Dunedin, NZ.

Nepe,T. (199I). E Hao ET nei Reanga Te Toi Huarewa Tipuna [Unpublished MA thesis]. University of Auckland, Auckland, NZ.

Smith, L.T. (1996). Nga Aho o te kakahu matauranga:The multiple layers of struggle by Maori in education [Unpublished PhD thesis]. University of Auckland. Auckland, NZ.

Taylor, D. (1996). The healing power of stories: The life-shaping power of our stories. New York, NY: Doubleday.

Thornton, A. (1999). Maori oral literature as seen by a classicist. Wellington, NZ: Huia.

Walker, R. J. (1978). The relevance of Maori myth and tradition. In M. King (Ed.), Tihei mauri ora: Aspects of maoritanga. Wellington, NZ: Methuen (NZ). 